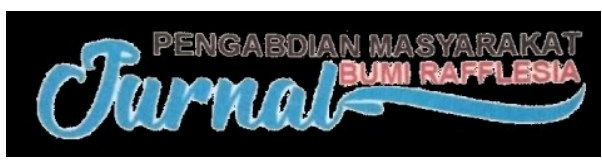

\title{
LOKAKARYA PENINGKATAN PROFESIONALISME GURU IPA MELALUI PENGUATAN KONTEN DAN PRODUK KARYA ILMIAH
}

\author{
Tomi Hidayat \\ Program Studi Pendidikan Biologi, Program Pascasarjana, \\ Universitas Muhammadiyah Bengkulu \\ tomihidayat@umb.ac.id
}

\begin{abstract}
ABSTRAK
Musyawarah Guru Mata Pelajaran (MGMP) Ilmu Pengetahuan Alam (IPA) merupakan sebuah wadah persatuan guru IPA yang berfungsi sebagai sarana diskusi untuk musyawarah hal-hal yang terkait dengan masalah yang ada pada IPA itu sendiri. Masalah yang dihadapi MGMP itu sendiri terkait dengan kualitas dari guru IPA Sekolah Menengah Petama dan Atas (SMP dan SMA) khususnya di Kabupaten Ciamis Jawa Barat yang terkait dengan penguasaan konten IPA yang masih sangat lemah. Program kegiaatan ini dilakukan atas beberapa tahapan yaitu (1) Penyampaian materi lokakarya dan pendampingan. Melakukan pelatihan dan pendampingan pada guru-guru IPA Kabupaten Ciamis dengan cara: a) Sosialisasi ke Sekolah-sekolah untuk menjelaskan akan diadakan lokakarya; b) Lokakarya implementasi silabus dan Rencana Pelaksanaan Pembelajaran IPA; c) Pelaksanaan Lokakarya guru IPA di STAI Al-Ma'arif Kabupaten Ciamis Jawa Barat; d) Pelaksanaan penulisan artikel produk karya ilmiah. (2) Simulasi dan Evaluasi, setelah memperoleh pengetahuan dan wawasan tentang penguatan konten IPA dan penulisan artikel ilmiah maka diadakan simulasi penerapan pengajaran konten IPA dan membuat produk karya ilmiah berupa artikel. Evaluasi atas capaian lokakarya yang telah dilaksanakan terhadap guru-guru IPA yang menerapkan penguasan konten IPA dan membuat produk karya ilmiah adalah telah di publikasi artikel ilmiah di Jurnal Scopus, yaitu Journal of Physics Conferences Series. Hasil kegiatan ini yaitu: (1) Peserta memahami strategi penguasaan konten IPA; (2) Peserta memahami proses pembuatan silabus dan Rencana Pelaksanaan Pembelajaran IPA; (3) Peserta memamahami pembuatan artikel ilmiah yang baik. (4) Peserta mengikuti seminar International Conference on Mathematic and Science Education di Bandung pada bulan Mei 2018 dan mensubmit artikel karya ilmiahnya di Journal of Physics Conferences Series; (5) Beberapa artikel publish di jurnal Journal of Physics Conferences Series.
\end{abstract}

Kata Kunci : Profesionalisme, Konten, IPA, Karya Ilmiah.

\section{PENDAHULUAN}

Salah satu usaha untuk meningkatkan profesionalisme dan kualitas guru IPA ialah melalui proses lokakarya. Peningkatan profesionalisme dan kualitas guru IPA melalui kegiatan lokakarya tersebut misalnya, lokakarya penguatan konten IPA dan menghasilkan karya ilmiah dalam bidang IPA. Dalam usaha meningkatkan kualitas sumber daya pendidikan, guru merupakan komponen sumber daya manusia yang harus dibina dan dikembangkan terus-menerus pada, baik itu kompetensi keilmuan dan kompetensi produk karya ilmah.

Peningkatan profesionalisme dan kualitas guru merupakan suatu proses yang harus dilakukan oleh setiap lembaga pendidikan dengan proses peningkatan sumber daya manusia sebagai salah komponen dari pendidikan itu sendiri. Guru yang profesionalisme dan berkualitas 
mampu mengikuti perkembangan ilmu pengetahuan dan teknologi (Dadan, 2012). Seiring dengan perkembangan dunia pendidikan yang semakin pesat, maka masyarakat menuntut lembaga pendidikan untuk lebih dapat melakukan perbaikan, inovasi, dan kreasi dalam menyampaikan konten pembelajaran dan strategi pembelajaran dalam menghadapi tantangan perkembangan ilmu pengetahuan dan teknologi sekarang ini (Trianto, 2007).

Masalah yang masih muncul dalam dunia pendidikan di Indonesia adalah masih rendahnya kualitas penguasaan konten pembelajaran dan produk karya ilmiah oleh guru pendidikan jika dibandingkan dengan negara-negara lain di Asia Tenggara. Hal itu berkaitan dengan bagaimana cara untuk mencapai tujuan pembelajaran yang telah ditentukan secara efektif dan efisien sehingga peserta didik diharapkan dapat menguasai konsepkonsep yang dipelajari dan penguasaan konten serta dapat menerapkan konsepkonsep tersebut dalam mengatasi masalahmasalah yang terjadi di lingkungannya (Dahar, 2003). Sebagian besar pembelajaran masih bersifat teacher centered yang masih kurang profesionalisme karena kurang menguasai konten (The North Central Regional Educational Laboratory and the Metiri Group, 2003).

Guru IPA seharusnya mampu menyampaikan konten IPA secara komprehensif dan kompleks, sehingga menciptakan suasana belajar yang bermakna dan berkesan bagi peserta didik serta peserta didik dapat mengaplikasikan konten IPA yang dipelajari dalam kehidupan sehari-hari (NRC, 1996). Siswa perlu mengerti apa makna belajar, apa manfaatnya dan bagaimana cara mencapainya, sehingga mereka akan menyadari bahwa apa yang mereka pelajari pada saat ini akan berguna bagi kehidupan masa depan (Trianto, 2010). Guru harus profesionalisme untuk dapat mengatasi permasalahan tersebut terutama dalam pembelajaran Science atau IPA.
Hakikat IPA dibangun atas dasar proses ilmiah, produk ilmiah, dan penguasaan konsep (Dahar, 2003). IPA juga dipandang pula sebagai suatu prosedur. IPA diartikan sebagai aspek proses, berarti semua kegiatan ilmiah untuk menyempurnakan pengetahuan tentang alam maupun untuk menemukan pengetahuan baru. IPA sebagai aspek produk, merupakan sebagai hasil dari proses yaitu berupa pengetahuan. IPA sebagai aspek prosedur, merupakan suatu cara yang dipakai untuk mengetahui sesuatu (Trianto, 2007). IPA sangat erat kaitannya dengan cara mencari tahu tentang alam secara sistematis. Dapat disimpulkan bahwa IPA bukan hanya penguasaan pengetahuan berupa faktafakta, konsep-konsep, atau prinsip-prinsip saja, tetapi juga merupakan suatu proses penemuan (BSNP, 2006). Pada tahun 2012, di bidang IPA/ Sains peringkat ke 64 dari 65 negara. (Organization for Economic Co-operation and Development/OECD, 2013).

Berdasarkan penjelasan yang telah diuraikan, bentuk kegiatan yang dilakukan untuk peningkatan profesionalisme guru adalah lokakarya penguasaan konten IPA dan produk karya ilmiah di STAI AlMa'arif Ciamis Jawa Barat. Penulis berharap artikel ini akan memberikan wawasan inovatif dan kreatif bagi guru khususnya calon guru IPA dalam mewujudkan tercapainya guru profesionalisme dalam hal konten IPA dan mampu membuat produk karya ilmiah.

\section{METODE KEGIATAN}

Metode yang digunakan dalam pengabdian ini adalah sebagai berikut:

\section{Situasi Permasalahan Mitra}

Khalayak sasaran dalam kegiatan pengabdian masyarakat ini adalah para guru IPA di Kabupaten Ciamis Jawa Barat 2016.

Penentuan kelompok sasaran yang akan dilibatkan dalam program pemberdayaan ini melalui proses sebagai berikut : 
1. Sosialisasi dan survey langsung pada lokasi yang akan menjadi sasaran dari kegiatan ini.

2. Bekerja sama dengan DIKNAS Pendidikan Kabupaten Ciamis.

3. Bekerja sama dengan seluruh sekolah SMA swasta dan negeri Kabupaten Ciamis.

4. Seluruh guru IPA SMP dan SMA swasta dan negeri Se-Kabupaten Ciamis dijadikan sasaran program pengabdian ini.

2. Bentuk Kegiatan

Adapun metode yang digunakan dalam kegiatan pengabdian (pelatihan pemberdayaan) ini adalah sebagai berikut:

1) Penyampaian Materi Pelatihan dan Pendampingan. Melakukan pelatihan dan pendampingan pada guru-guru IPA Kabupaten Ciamis dengan cara:

a. Sosialisasi ke Sekolah-sekolah untuk menjelaskan akan diadakan lokakarya.

b. Lokakarya implementasi silabus dan Rencana Pelaksanaan Pembelajaran IPA.

c. Pelaksanaan Lokakarya guru IPA di STAI Al-Ma'arif Kabupaten Ciamis Jawa Barat.

d. Pelaksanaan penulisan artikel produk karya ilmiah.

2) Simulasi dan Evaluasi

Setelah memperoleh pengetahuan dan wawasan tentang penguatan konten IPA dan penulisan artikel ilmiah maka diadakan simulasi penerapan pengajaran konten IPA dan membuat produk karya ilmiah berupa artikel. Evaluasi atas capaian lokakarya yang telah dilaksanakan terhadap guru-guru IPA yang menerapkan penguasan konten IPA dan membuat produk karya ilmiah adalah telah di publikasi artikel ilmiah di Jurnal Scopus, yaitu Journal of Physics Conferences Series di Bandung pada Bulan Mei 2018.

\section{HASIL DAN PEMBAHASAN}

Hasil dari kegiatan lokakarya yang telah dilakukan dapat diuraikan sebagai berikut:

a. Peserta memahami strategi penguasaan konten IPA.

b. Peserta memahami proses pembuatan silabus dan Rencana Pelaksanaan Pembelajaran IPA.

c. Peserta memamahami pembuatan artikel ilmiah yang baik.

d. Peserta mengikuti seminar International Conference on Mathematic and Science Education di Bandung pada bulan Mei 2018 dan mensubmit artikel karya ilmiahnya di Journal of Physics Conferences Series. Beberapa artikel publish di jurnal Journal of Physics Conferences Series tersebut.

Secara umum, peserta sangat antusias dan intensif melakukan komunikasi dan konfirmasi baik secara langsung maupun lewat online di medsos tentang penulisan artikel ilmiah. Para guru IPA di Kabupaten Ciamis Jawa Barat memiliki pmehaman baru mengenai bagaimana menulis artikel untuk menembus jurnal internasional yang terindeks scopus.

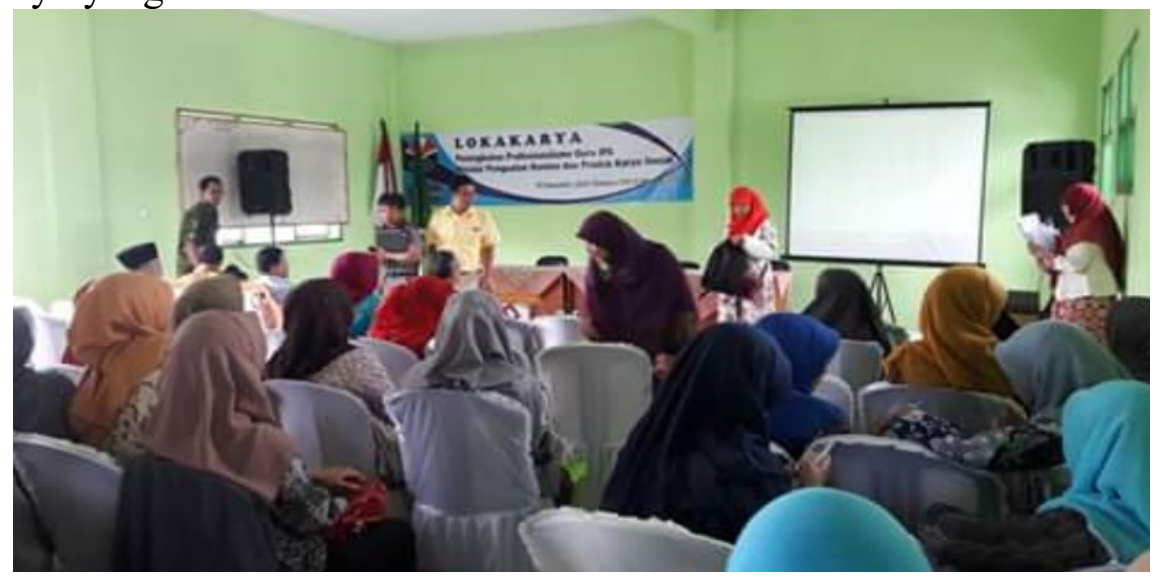




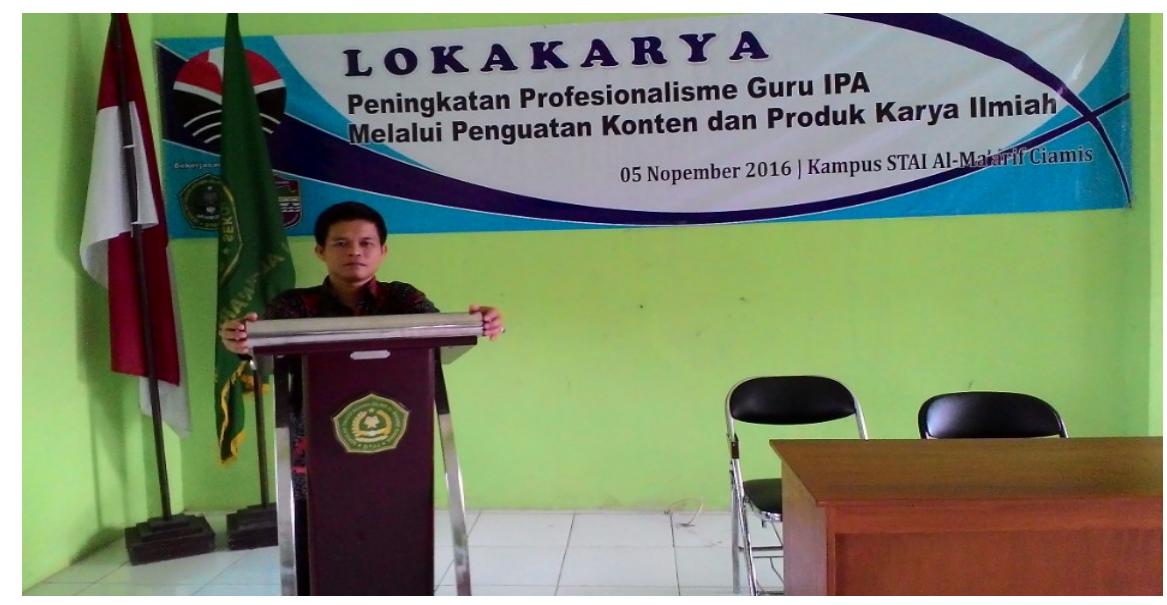

Gambar 1. Kegiatan Lokakarya

Tabel 1. Jadwal kegiatan lokakarya

\begin{tabular}{|c|c|c|c|}
\hline No & Waktu & Acara & Penanggung Jawab \\
\hline 1 & $07.30-07.35$ & Pembukaan & $\mathrm{MC}$ \\
\hline 2 & $07.35-07.40$ & Pembacaan ayat suci Al-Quran dan Doa & Mahasiswa STAI \\
\hline 3 & $07.40-07.50$ & Sambutan Ketua STAI & \\
\hline 4 & $07.50-08.00$ & $\begin{array}{l}\text { Sambutan Direktur Pasca atau Ketua Prodi } \\
\text { Pendidikan IPA }\end{array}$ & \\
\hline 5 & $08.00-08.20$ & $\begin{array}{l}\text { Sambutan \& Pembukaan Lokakarya dan } \\
\text { Workshop }\end{array}$ & \\
\hline 6 & $08.20-08.30$ & Tutup/Break & \\
\hline \multirow[t]{2}{*}{7} & \multirow[t]{2}{*}{$08.30-10.30$} & $\begin{array}{l}\text { Pendalaman/perluasaan materi IPA dengan } \\
\text { tema "STEM Education" }\end{array}$ & \\
\hline & & $\begin{array}{l}\text { Pendalaman/Perluasan Materi Fisika } \\
\text { Dengan tema "Global Warming dan } \\
\text { perubahan iklim" }\end{array}$ & \\
\hline \multirow[t]{2}{*}{8} & \multirow[t]{2}{*}{$10.30-12.30$} & $\begin{array}{l}\text { Pendalaman/Perluasaan Materi Biologi } \\
\text { dengan tema "Biologi Molekular" }\end{array}$ & \\
\hline & & $\begin{array}{l}\text { Pendalaman/perluasan Materi Kimia dengan } \\
\text { Tema "Nano Teknologi" }\end{array}$ & \\
\hline 9 & $12.30-13.30$ & Ishoma & \\
\hline \multirow[t]{4}{*}{10} & \multirow[t]{4}{*}{$13.30-15.30$} & PTK \& KI Kelas A=Fisika & \\
\hline & & PTK \& KI Kelas B=Biologi & \\
\hline & & PTK \& KI Kelas C=Kimia & \\
\hline & & PTK \& KI Kelas IPA & \\
\hline 11 & $15.30-17.00$ & Pengumpulan Hasil PTK, KI dan Penutupan & \\
\hline
\end{tabular}

IPA melalui kuliah umum oleh narasumber berikut:

Proses kegiatan lokakarya sebagai

a. Dilakukan persiapan penyampaian materi tentang pendalaman materi dengan tema "STEM Education", untuk bidang studi Fisika dengan tema "Global warming dan perubahan iklim", untuk bidang studi Biologi dengan tema "Biologi 
Molekuler", dan untuk bidang studi Kimia, dengan tema "Nano Teknologi".

b. Hasil dari penyampaian materi diterapkan oleh para peserta lokakrya, yaitu guru untuk membuat artikel PTK di kelas paralel. Pendampingan di dilakukan dan dikonsultasikan kepada dosen pendamping dan para narasumber di dalam kelas paralel sesuai bidang keahlian para guru.

c. Pada akhir kegiatan, dilakukan pengumpulan artikel ilmiah yang telah dibuat dan didampingi serta dikonsultasikan pada dosen pembimbing.

d. Tahap evaluasi dan refleksi kegiatan lokarya ini, yaitu dengan melakukan pengumpulan soft file artikel untuk didaftarkan pemakalah di International Conference on Mathematic and Science Education di Bandung pada bulan Mei 2018 dan mensubmit artikel karya ilmiahnya di Journal of Physics Conferences Series. Hasil nya beberapa artikel publish di jurnal Journal of Physics Conferences Series Quarter 3 (Q3).

\section{KESIMPULAN DAN SARAN}

\section{A. Kesimpulan}

Berdasarkan keseluruhan proses lokakarya yang telah dilakukan di dapatkan kesimpulan sebagai berikut:

1. Penguatan konten IPA sangat penting, karena membuat peserta didik mengetahui makna dari materi yang dipelajari. Guru yang profesinal adalah guru yang menguasai konten.

2. Guru profesionalisme merupakan seorang pendidik yang mampu menulis artikel PTK dan sebagai produk karya ilmiah yang baik adalah mempublikasikannya ke tengahtengah masyarakat, sehingga dikonsumsi masyarakat untuk dimanfaatkan dikehidupan.

\section{B. Saran}

1. Perguruan Tinggi sebagai LPTK sebaiknya melakukan lokakarya yang bersifat lebih praktik dengan pendekatan personal dan sesuai dengan kebutuhan guru baik di bidang belajar pembelajaran dan memfasilitasi guru-guru dalam megembangkan karir, misalnya kenaikan pangkat dengan syarat mempunyai artikel yang telah dipublikasikan dalam jurnal yang terindeks.

2. Pendampingan secara intensif perlu di lakukan terhadap guru, terutama dalam menyampaikan trik atau strategi dalam menembus jurnal nasional terakreditasi maupun jurnal internasional terindek scopus.

\section{DAFTAR PUSTAKA}

Badan Standar Nasional Pendidikan (BSNP). 2006. Permendiknas No. 22 Tahun 2006 Tentang Standar Isi. Jakarta: Departemen Pendidikan Nasional.

Dadan. 2012. Kreatif dalam membuat Website Profesional. Jakarta: Elex Media

Menggagas Science Education yang Baik Terkait Esensial 21stCentury Skills. Disampaikan pada Seminar Nasioanal Science Education ke IV, Unesa: Surabaya.

Dahar, R.W. (2003). Aneka Wacana Pendidikan Ilmu Pengetahuan Alam. Bandung.

NRC. 1996. National Research Council: Nature of Science. NRC Publishing.

OECD. 2013. PISA 2012 Assessment and Analytical Framework: Mathematics, Reading, Science, Problem Solving and Financial Literacy. OECD Publishing.

The North Central Regional Educational Laboratory and the Metiri Group. (2003). enGauge 21st century skills: Literacy in the digital age. Los Angeles: The Institute of Education Sciences (IES). 
Trianto. 2007. Model-model Pembelajaran Inovatif Berorientasi Konstruktivistik. Jakarta: PT. Bumi Aksara.

Trianto. 2010. Model Pembelajaran Terpadu. Jakarta: PT. Bumi Aksara.

Wenna, Made. 2009. Strategi Pembelajaran Inovatif Kontemporer. Jakarta: Bumi Aksara 